\title{
Total serum IgE is associated with asthma independently of specif- ic IgE levels
}

\author{
J. Sunyer, J.M. Antó, J. Castellsagué, J.B. Soriano, J. Roca, and \\ the Spanish Group of the European Study of Asthma
}

Total serum IgE is associated with asthma independently of specific IgE levels. J. Sunyer, J.M. Antó, J. Castellsagué, J.B. Soriano, J. Roca, and the Spanish Group of the European Study of Asthma. @ERS Journals Ltd 1996.

ABSTRACT: In this study we aimed to assess whether the association between asthma (defined by symptoms and bronchial responsiveness) and total immunoglobulin E (IgE) levels was independent of specific IgE levels to common aeroallergens.

A general population-based sample, supplemented with symptomatic individuals, comprising 1,916 young adults, aged 20-44 years, from five areas of Spain, performed a face-to-face respiratory questionnaire, and spirometry, and had total and specific serum IgE levels to mites, pets and moulds recorded. In 1,626 of the subjects, a dose-response methacholine challenge test was completed.

Subjects reporting current attacks of asthma showed an association with total IgE (odds ratio $(\mathrm{OR})$ for $\mathrm{IgE}>100 \mathrm{kU} \cdot \mathrm{L}^{-1}=4.73,95 \%$ confidence intervals $(95 \% \mathrm{CI}$ ) = 2.01-11.12, adjusted for specific IgE, sex, age, smoking, forced expiratory volume in one second (FEV1), and area), which did not vary by bronchial responsiveness. The association between total IgE and asthma also occurred among those with negative specific IgE antibodies (OR 18.0; 95\% CI 13.9-120). Individuals with current wheezing and bronchial responsiveness without attacks of asthma also showed an adjusted association with total IgE (OR 4.96; 95\% CI 2.32-10.6), which remained for persons without specific IgE (OR 5.86; 95\% CI 2.18-1.7).

These findings reinforce previous evidence that asthma is associated with increased levels of total IgE, even in subjects negative for specific IgE to common aeroallergens.

Eur Respir J., 1996, 9, 1880-1884.
Departament d'Epidemiologia i Salut Pública, Institut Municipal d'Investigació Medica (IMIM), and Servei de Pneumologia i Al.lèrgia Respiratòria, Hospital Clínic i Provincial, Barcelona, Spain.

Correspondence: J. Sunyer

Departament d'Epidemiologia i Salut Pública Institut Municipal d'Investigació Mèdica (IMIM)

Doctor Aiguader 80

E-08003 Barcelona

Spain

Keywords: Allergens

asthma

atopy

bronchial responsiveness

specific serum immunoglobulin E

total serum immunoglobulin $\mathrm{E}$

Received: December 181995

Accepted after revision May 51996

Supported in part by a FIS grant (No. 93/0393), Madrid, and CIRIT (No. XT9540), Barcelona, Spain.
Population studies have shown an association between prevalence of asthma or bronchial hyperresponsiveness and total serum immunoglobulin E (IgE) levels [1-6], independent of specific reactivity to common allergens or symptoms of allergy. This finding suggests a close interrelationship between asthma and total IgE, even in nonatopic subjects, and it has challenged the concept of intrinsic asthma [1].

Some of the previous epidemiological studies defined asthma according to reported diagnosis of asthma [1,2], which could have led to a possible diagnostic bias. Other studies assessed bronchial responsiveness [3-5], but not symptoms of asthma. Only one study [6] combined both symptoms and bronchial responsiveness, though it was restricted to children. Although a gold standard for the definition of asthma has not yet been established [7], the combination of reported respiratory symptoms and nonspecific bronchial hyperresponsiveness has been shown to correctly identify patients with severe asthma [8-10].

We assessed the relationship between total IgE levels and asthma, defined both by reported symptoms and bronchial responsiveness, in a random sample of young adults from five areas of Spain participating in the European Community Respiratory Health Survey (ECRHS) [11]. We hypothesized that there was an association between total IgE and asthma both in subjects with specific IgE to common aeroallergens and subjects without specific IgE. This association could indicate an allergic nature of asthma in nonatopic persons.

\section{Methods}

\section{Study population}

A sample of 16,884 subjects, aged 20-44 yrs, was randomly selected from the general population in the census of five areas in Spain (Albacete, Barcelona, Galdakao, Huelva and Oviedo) that participated in the ECRHS. A short and simple screening respiratory questionnaire was administered by mail and phone to $85 \%$ of the subjects. In a second phase, a subcohort of 3,310 of the original sample (approximately 20\%) was selected at random. In addition, 1,029 subjects (9\%) who reported "symptoms related with asthma" in the short respiratory interview and who were not included in the random subcohort were invited to take part in the second phase of the study. "Symptoms related with asthma", an operative criterion established in the ECRHS protocol [11], was used to 
oversample possible asthma subjects in the second phase of the study. It was defined as a positive answer to at least one of the following questions of the short respiratory questionnaire: "Have you been woken by an attack of shortness of breath at any time in the last 12 months?"; "Have you had an attack of asthma in the last 12 months?"; or "Are you currently taking any medicine (including inhalers, aerosols or tablets) for asthma?".

From March 1992 to April 1993, subjects were invited to attend a centre in each city to complete a face-toface respiratory questionnaire, to undergo a spirometry and a dose-response methacholine challenge test, and to have total and specific serum IgE levels measured. All of the tests were performed during the same visit. From the 3,310 individuals of the random subcohort, 1,371 (41\%) attended the clinic; and from the 1,029 with symptoms but not in the random sample, $545(53 \%)$ did so. Individuals with symptoms from the random sample did not differ from those oversampled in terms of response rate, age, sex, residence area, smoking and IgE.

The study protocol was approved by the Institutional Review Board of the participating centres and patients gave written informed consent.

\section{Definition of asthma}

Since the definition of asthma is controversial, different definitions of asthma were used based on symptoms and bronchial responsiveness. "An attack of asthma" was the symptom that appeared more valid regarding concurrent measurements of pulmonary function or nonspecific airway responsiveness [11-13]. Therefore, "current asthma" was defined as a patient who reported at least one attack of asthma in the previous 12 months [11], and "past asthma" as a report of an attack of asthma ever but not in the last 12 months. In order to overcome the diagnostic bias related to the use of the word "asthma", other symptoms were selected to define categories that might be likely to include subjects with asthma. Wheezing showed a high sensitivity for bronchial hyperresponsiveness $[11,14]$ and, in combination with bronchial responsiveness, a good specificity for asthma diagnosis [9, 10]. "Current wheezing only" was defined as a report of wheezing or whistling at any time in the last 12 months among those without attacks of asthma [11]. Other symptoms, such as nocturnal dyspnoea or feeling tightness in the chest have been proven to be related to bronchial hyperresponsiveness $[8,14]$. "Other asthma related symptoms" were defined as individuals reporting symptoms such as shortness of breath at night, tightness in the chest at night, or taking medicines for asthma in the last 12 months, among those without attacks of asthma or wheezing. Since the combination of reported respiratory symptoms, in particular wheezing, and nonspecific bronchial hyperresponsiveness has been shown to correctly identify patients with severe asthma [8-10] the above definitions were combined with bronchial responsiveness.

\section{Bronchial hyperresponsiveness}

Subjects underwent baseline spirometry (Biomedin, $\mathrm{Pa}$ dova, Italy), performing at least three acceptable (repeatable within $5 \%$ or $100 \mathrm{~mL}$ ) manoeuvres to measure forced expiratory volume in one second (FEV1) [15]. Bronchial hyperresponsiveness was measured by means of a methacholine-inhalation challenge. Standard methacholine solutions (Hoffman La Roche, London, UK) were prepared by the Department of Pharmacy of one of the participating centres. After inhaling nebulized saline, each methacholine dose was administered using a Mefar dosimeter, according to the ECRHS protocol [11]. The methacholine challenge test was performed only if the best FEV1 after saline inhalation was more than $90 \%$ of the baseline FEV1. Increasing concentrations of methacholine, from 0.195 to $100 \mathrm{mg} \cdot \mathrm{mL}^{-1}$, were sequentially inhaled. The challenge was terminated when FEV1 fell by more than $20 \%$ from the best saline FEV1 or after $1 \mathrm{mg}(5.117 \mu \mathrm{M}$ inhaled) of methacholine has been given. Bronchial responsiveness was defined as a fall in FEV1 by $\geq 20 \%$ of the FEV1 saline inhalation.

\section{IgE measurements}

Total serum IgE and specific serum IgE levels against Dermatophagoides pteronyssinus, cat dander, timothy grass, Cladosporium and Parietaria were measured by the capsulated hydrophilic carrier (CAP) method (Kabi Pharmacia, Upssala, Sweden) in one of the participating centres. Values were expressed in $\mathrm{kU} \cdot \mathrm{L}^{-1}$ [11]. Atopy was defined as an IgE specific response to at least one antigen. Nonatopy was a negative response to all the antigens.

\section{Analysis}

Bronchial hyperresponsiveness was considered present if the concentration of methacholine to produce a $20 \%$ fall in FEV1 $\left(\mathrm{PC}_{20}\right)$ was $\leq 100 \mathrm{mg} \cdot \mathrm{mL}^{-1}$. It was considered absent if the $\mathrm{PC}_{20}$ was $>100 \mathrm{mg} \cdot \mathrm{mL}^{-1}$. Since $\mathrm{IgE}$ values are concentrations that exhibit a skewed distribution, IgE was transformed to the logarithmic scale. Log transformation of total IgE showed a reasonably normal distribution, but log transformations of specific IgE levels did not. Specific IgE values were treated as dichotomous variables, using a cut-off value of $0.35 \mathrm{kU} \cdot \mathrm{L}^{-1}$. Total $\operatorname{IgE}$ was assessed both as $\log (\operatorname{IgE})$ categorized into quartiles, included as dummy variables, and as a continuous variable. Given that similar results were obtained with both methods, only those corresponding to the former method are presented.

The association of asthma symptoms and bronchial hyperresponsiveness measured as a binary outcome with total $\operatorname{IgE}$ was calculated by the odds ratio (OR), using standard methods of logistic regression analysis [15]. Subjects without symptoms of asthma or PC20 $>100 \mathrm{mg} \cdot \mathrm{mL}^{-1}$ were considered as the outcome group of comparison. As IgE showed a moderate decrease with increasing age, and higher levels in males than in females, all the analyses with $\operatorname{IgE}$ were adjusted for sex and age (in years). Other potential confounders assessed were current smoking (defined as at least one cigarette-day ${ }^{-1}$ in a month), and baseline FEV1 (the latter for bronchial responsiveness). In addition, all the analyses were adjusted for area, as a dummy variable, since there were differences in participation 
between cities and its inclusion also made it possible to control for differences in technicians and interviewers between centres. Adjustment for confounding variables and assessment of trends of the variables were analysed using logistic regression analysis [16]. Variables that modify the association between IgE and asthma symptoms were determined by testing the significance of interactions in the logistic regression model.

\section{Results}

A total of 1,916 individuals (1,626 with complete information and 290 who did not finish the bronchial responsiveness test) were included in the study (table 1). The 290 refused the methacholine challenge test or were unable to perform adequately (including 24 who withdrew from the test and 56 who had a fall in FEV1 $>10 \%$ from baseline following saline, precluding further testing). Nonparticipants did not show any difference with respect to gender or age $(51 \%$ were females, mean age $32 \mathrm{yrs})$ from those who participated $(50 \%$ females, mean age 32 yrs). However, more females with no symptoms (53\%) declined to participate than females with symptoms (44\%) $(\mathrm{p}=0.02)$ (table 1).

Individuals with current asthma showed markedly higher levels of total serum IgE (geometric mean $155 \mathrm{kU} \cdot \mathrm{L}^{-1}$ ) than those reporting past asthma $\left(55 \mathrm{kU} \cdot \mathrm{L}^{-1}\right)$, current wheezing only $\left(50 \mathrm{kU} \cdot \mathrm{L}^{-1}\right)$, other asthma-related symptoms $\left(33 \mathrm{kU} \cdot \mathrm{L}^{-1}\right)$ or no symptoms $\left(30 \mathrm{kU} \cdot \mathrm{L}^{-1}\right)$. The proportion of subjects with IgE levels higher than 100 $\mathrm{kU} \cdot \mathrm{mL}^{-1}$ or specific IgE against at least one common

Table 1. - Number of subjects according to participation in the present study, by gender and asthma-related symptoms

\begin{tabular}{|c|c|c|c|c|c|c|c|}
\hline & \multirow[t]{2}{*}{ Eligible* } & \multicolumn{2}{|c|}{$\begin{array}{l}\text { Complete } \\
\text { information }\end{array}$} & \multicolumn{2}{|c|}{$\begin{array}{l}\text { No. tested } \\
\text { for BR }\end{array}$} & \multicolumn{2}{|c|}{$\begin{array}{c}\text { Non- } \\
\text { participants }\end{array}$} \\
\hline & & $\mathrm{n}$ & $\%$ & $\mathrm{n}$ & $\%$ & $\mathrm{n}$ & $\%$ \\
\hline \multicolumn{8}{|l|}{ Females } \\
\hline Symptoms & 625 & 263 & 42 & 86 & 14 & 276 & 44 \\
\hline No symptoms & s 1289 & 519 & 40 & 91 & 7 & 679 & 53 \\
\hline \multicolumn{8}{|l|}{ Males } \\
\hline Symptoms & 637 & 279 & 44 & 49 & 8 & 309 & 49 \\
\hline No symptoms & s 1242 & 565 & 45 & 64 & 5 & 613 & 49 \\
\hline All & 3793 & 1626 & 43 & 290 & 8 & 1877 & 49 \\
\hline
\end{tabular}

*: subjects who completed the short-term respiratory questionnaire ( $85 \%$ of the original sample); BR: bronchial responsiveness.

Table 2. - Distribution of subjects by asthma symptoms and total IgE levels in quartiles and specific IgE against at least one common allergen

\begin{tabular}{lcccccc}
\hline & & \multicolumn{4}{c}{ Total IgE $\left(\mathrm{kU} \cdot \mathrm{L}^{-1}\right)$} & \multicolumn{3}{c}{ Specific } \\
\cline { 3 - 6 } & IgE \\
\cline { 3 - 6 } Variable & $\mathrm{n}$ & $\%$ & $\%$ & $\%$ & $\%$ & $\%$ \\
\hline Current asthma & 80 & 10 & 9 & 22 & 60 & 69 \\
Past asthma & 75 & 11 & 23 & 28 & 39 & 60 \\
Current wheezing only & 517 & 18 & 25 & 25 & 32 & 32 \\
Other asthma symptoms & 299 & 27 & 28 & 22 & 23 & 29 \\
No asthma symptoms & 945 & 30 & 26 & 23 & 21 & 22 \\
\hline
\end{tabular}

IgE: immunoglobulin E; Subj.: subjects; +ve: positive.
Table 3. - Relationship between asthma symptoms and total $\lg \mathrm{E}$

\begin{tabular}{lccc}
\hline & \multicolumn{2}{c}{ Total $\mathrm{IgE} \geq 100 \mathrm{kU} \cdot \mathrm{L}^{-1}$} & $\mathrm{p}$-value \\
\cline { 2 - 3 } Variable & $\mathrm{OR} *$ & $95 \% \mathrm{CI}^{*}$ & for trend \\
\hline Current asthma & 4.73 & $(2.01-11.12)$ & $<0.001$ \\
Past asthma & 2.34 & $(0.94-3.0)$ & $>0.5$ \\
Current wheezing only & 2.20 & $(1.53-2.42)$ & $<0.001$ \\
Other asthma symptoms & 1.27 & $(0.83-1.93)$ & $>0.1$ \\
\hline
\end{tabular}

IgE: immunoglobulin E; OR: odds ratio; $95 \%$ CI: 95\% confidence interval. *: OR and $95 \% \mathrm{CI}$ for $\mathrm{IgE}>100 \mathrm{kU} \cdot \mathrm{L}^{-1}$ referred to $\operatorname{IgE} \leq 13 \mathrm{kU} \cdot \mathrm{L}^{-1}$ adjusted for specific $\operatorname{IgE}$, sex, age in years, area, and smoking status.

allergen was also greater among the group of individuals with asthma (table 2). The adjusted association between current asthma and total IgE was very strong and progressive (table 3 ). This association persisted after adjusting for specific IgE levels. Past asthma showed a less consistent and nonsignificant association with total $\operatorname{IgE}$ levels. Wheezing showed a statistically significant association with total $\mathrm{IgE}$, although weaker, and the association for other symptoms was even lower.

Table 4 presents the associations with IgE after including bronchial responsiveness in the definitions of asthma. Bronchial responsiveness was observed in $242(15 \%)$ out of 1626 individuals. Among these associations, current asthma and past asthma showed a similar relationship with total IgE, irrespective of including bronchial responsiveness in the outcome definition. The associations for wheezing and other asthma-related symptoms became stronger after including bronchial responsiveness.

When only individuals without specific $\operatorname{IgE}$ antibodies were assessed, the associations of current asthma, past asthma and wheezing together with bronchial responsiveness with total IgE remain significant (table 5). Very

Table 4. - Relationship between asthma symptoms with bronchial responsiveness (BR) and total IgE

\begin{tabular}{lcccccr}
\hline & Subj. & \multicolumn{3}{c}{ Total IgE $>100$} & p-value \\
\cline { 3 - 6 } Variable & $\mathrm{n}$ & $\%$ & $\mathrm{OR}^{*}$ & $95 \% \mathrm{CI}^{*}$ & for trend \\
\hline Current asthma+BR & 37 & 57 & 3.62 & $(1.03-12.64)$ & $<0.01$ \\
Past asthma+BR & 27 & 48 & 2.01 & $(0.72-6.51)$ & 0.05 \\
Current wheezing+BR & 92 & 43 & 4.96 & $(2.32-10.59)$ & $<0.01$ \\
Other symptoms+BR & 16 & 48 & 3.02 & $(0.65-13.96)$ & $<0.05$ \\
\hline
\end{tabular}

*: OR and $95 \% \mathrm{CI}$ for $\operatorname{IgE}>100 \mathrm{kU} \cdot \mathrm{L}^{-1}$ referred to $\operatorname{IgE} \leq 13$ $\mathrm{kU} \cdot \mathrm{L}^{-1}$, adjusted for specific IgE, sex, age in years, area, smoking status and basal FEV1. For definitions see legend to table 3.

Table 5. - Relationship between asthma and total IgE in persons without specific IgE antibodies

\begin{tabular}{lcccc}
\hline & Subj. & \multicolumn{2}{c}{ Total $\mathrm{IgE}>100$} & $\mathrm{p}$-value \\
\cline { 3 - 4 } Variable & $\mathrm{n}$ & OR* & $95 \% \mathrm{CI}^{*}$ & for trend \\
\hline Current asthma & 25 & 18.0 & $(13.9-120)$ & $<0.01$ \\
Past asthma & 25 & 2.31 & $(0.69-7.78)$ & $<0.05$ \\
Current wheezing+BR & 61 & 5.86 & $(2.18-12.75)$ & $<0.01$ \\
\hline
\end{tabular}

*: OR and $95 \% \mathrm{CI}$ for $\operatorname{IgE}>100 \mathrm{kU} \cdot \mathrm{L}^{-1}$ referred to $\operatorname{IgE} \leq 13$ $\mathrm{kU} \cdot \mathrm{L}^{-1}$, adjusted for sex, age in years, area, and smoking status. For definitions see legends to tables 1 and 3 . 
few subjects $(n=8)$ with other asthma-related symptoms and bronchial hyperresponsiveness showed negative specific IgE antibodies, which precluded the assessment in this group.

\section{Discussion}

The present study confirms the association between asthma and total IgE independent of atopy (i.e. specific $\mathrm{IgE})$. Studying a general population of young adults in a Southern European country reinforces the general validity of the relationship between total $\mathrm{IgE}$ and asthma in nonatopic subjects, previously reported in the United States $[1,2]$. The combination of reported symptoms and bronchial responsiveness strengthens the validity of present results.

IgE is produced by B-cells under the control of T-cells of the type $2 \mathrm{~T}$-helper (Th2) phenotype in atopic individuals [16]. In nonatopic persons, the underlying mechanisms of the association between total $\mathrm{IgE}$ and asthma are less clear. Increased total $\mathrm{IgE}$ in individuals with negative specific IgE to common allergens can be a marker both of allergy [17], and inflammation [18]. Although we had tested the major allergens (i.e. mites, pets and moulds), total IgE independent of specific $\operatorname{IgE}$ can simply express allergy to nontested environmental allergens, such as other indoor allergens [19]. IgE could also express a humoral autoimmunity, since specific reactivity against human proteins with structural similarity to allergens has been described [20]. Even if untested allergens are irrelevant, the possibility of allergic explanation is still plausible, since the synthesis of human IgE may be directly regulated by basophils and mast cells, independently of the allergen-specific T-cell/B-cell interaction [21, 22], suggesting an allergen provocation of nonspecific IgE production [23]. A different interpretation suggests that total $\mathrm{IgE}$ could be a consequence of asthma, a marker of nonallergic inflammation [18]. A further possibility is that the relationship observed might not be causal, since it can only express the co-inheritance of two genetic traits associated to atopy and bronchial responsiveness [24, 25]. The observed association between both phenomena (i.e. total $\operatorname{IgE}$ and bronchial hyperresponsiveness) in nonsymptomatic individuals might support such a noncausal association.

From the epidemiological point of view, we envisaged that the present study would overcome some of the limitations of previous population studies. It should be noted that measuring asthma by questionnaires is limited [7], and that studying the relationship between $\operatorname{IgE}$ and asthma, defining asthma by reported symptoms [1, 2], faces the likelihood of diagnostic bias. Those subjects with high levels of total $\mathrm{IgE}$ or specific $\operatorname{IgE}$ are more likely to be labelled as asthmatics. The strong association between attacks of asthma and bronchial hyperresponsiveness (i.e. $70 \%$ of individuals reporting asthma showed bronchial responsiveness; $\mathrm{OR}=9.5$ ) as compared with the weaker association between wheezing and airway responsiveness (i.e. only $22 \%$ of this group showed bronchial responsiveness; $\mathrm{OR}=2.4$ ) reinforces the validity of the reported symptoms for defining asthma. Moreover, subjects reporting both the asthma symptoms but not asthma attacks (i.e. wheezing or other asthma-related symptoms) and bronchial responsiveness included probable undiagnosed asthma subjects $[9,10]$, who were not susceptible to the diagnostic bias. The finding of an association with $\operatorname{IgE}$ in this group, similar to that in those reporting asthma, reduces the possible effects of a diagnostic bias.

Total IgE level was age- and sex-dependent. Some authors $[1,18]$ have transformed $\log \operatorname{IgE}$ values into $\mathrm{Z}$ scores, in order to control the large differences in the serum concentration of total IgE by extreme age groups. However, IgE showed small differences by age in the present study (around $1.5 \mathrm{kU} \cdot \mathrm{L}^{-1}$ for each interval of 5 yrs). Therefore, a standard method of adjustment for confounding variables, such as multiple regression analysis was used. The IgE difference by sex was more pronounced than by age (approximately $10 \mathrm{kU} \cdot \mathrm{L}^{-1}$ ). Stratification of results by sex did not modify any of the observed associations.

There was a substantial nonresponse due to the unwillingness of healthy young persons to attend the hospital. However, nonresponse is unlikely to explain the present findings. Subjects who did not attend the centre, did not show any difference by sex or age compared with those who participated, but more females with no symptoms declined to participate than females with symptoms. This fact may not invalidate the strong association between asthma and IgE, since this was also obtained in males, for whom there were not apparent differences between participants and nonparticipants, and in the group as a whole after adjusting for sex. The proportion of nonresponders also differed between areas (from 30-50\% from those randomly selected). However, the association between IgE and asthma was also found when only areas with the highest response rates were included. Moreover, the inclusion of a dummy variable for area controls this possible selection bias. Invasiveness of the bronchial challenge may also explain the low response in this and other studies $[5,7,10$, 12]. However, the relationship between asthma and IgE after excluding those who did not complete the bronchial challenge did not differ from the relationship when including all participants. Nonresponse is a common problem among all centres of the ECRHS [26]. Studies conducted with data from all areas showed that adjustment for nonresponse did not modify the results [26].

In summary, this study reinforces the evidence provided by other studies on asthma [1,2] and bronchial responsiveness [3-6] that asthma is associated with total $\operatorname{IgE}$, even in subjects with negative specific IgE. Whether this was explained by an allergic nature of asthma in nonatopics, or due to a noncausal association between asthma and total IgE (recent genetic epidemiological studies have suggested a co-inheritance) [24, 25], was beyond the sphere of the present paper. The underlying mechanisms of present findings could have preventive and therapeutic implications.

Acknowledgements: The authors thank M. Pulido, for editorial assistance, and L. Santamaría for comments on immunology.

Spanish Group of the European Study of Asthma

Centres and investigators: J.M. Anto (Principal Investigator); Albacete: J. Martinez-Moratalla, E. Almar, M. Arevalo, A. Mateos, A. Sanchez, M. Vizcaya; Barcelona: J. Sunyer, F. Burgos, J. Castellsagué, M.B. Galobardes, J. Roca, J.B. Soriano, A. Tobías; Galdakao: N. Muniozguren, M. Errazola, A. Capelastegui, J. Ramos; Huelva: J.A. Maldonado, J.L. Sanchez, A. Pereira, J. Gravalos; and Oviedo: R. Quiros, J. Azofra, L. Palenciano, F. Payo, G. Rego, A. Vega. 


\section{References}

1. Burrows B, Martinez FD, Halonen M, Barbee RA, Cline MG. Association of asthma with serum IgE levels and skin-test reactivity to allergens. N Engl J Med 1989; 320: 271-277.

2. Freidhoff LR, Marsh DG. Relationship among asthma, serum IgE levels, and skin test reactivity to inhaled allergens. Int Arch Allergy Appl Immunol 1993; 100: 355361 .

3. Grainger DN, Stenton SC, Aver AJ, Duddridge M, Walters $\mathrm{EH}$, Hendrick DJ. The relationship between atopy and nonspecific bronchial responsiveness. Clin Exp Allergy 1990; 20: 181-187.

4. O'Connor GT, Sparrow D, Segal MR, Weiss ST. Smoking, atopy, and methacholine airway responsiveness among middle-aged elderly men: the Normative Aging Study. Am Rev Respir Dis 1989; 140: 1520-1526.

5. Tollerud DJ, O'Connor GT, Sparrow D, Weiss ST. Asthma, hay fever, and phlegm production associated with distinct patterns of allergy skin test reactivity, eosinophilia, and serum IgE levels: the Normative Aging Study. Am Rev Respir Dis 1991; 144: 776-781.

6. Sears MR, Burrows B, Flannery EM, Herbison GP, Hewitt CJ, Holdaway MD. Relation between airway responsiveness and serum IgE in children with asthma and in apparently normal children. $N$ Engl J Med 1991; 325: 1067-1071.

7. Pattemore PK, Asher MI, Harrison AC, Mitchell EA, Rea HH, Stewart AW. The interrelationship among bronchial hyperresponsiveness, the diagnosis of asthma, and asthma symptoms. Am Rev Respir Dis 1990; 142: 549-554.

8. Mortagy AK, Howell JBL, Waters WE. Respiratory symptoms and bronchial reactivity: identification of a syndrome and its relation to asthma. $B r \operatorname{Med} J$ 1986; 293: 525-529.

9. Toelle BG, Peat JK, Salome CM, Mellis CM, Woolcock AJ. Toward a definition of asthma for epidemiology. Am Rev Respir Dis 1992; 146: 633-637.

10. Peat JK, Toelle BG, Salome CM, Woolcock AJ. Predictive nature of bronchial responsiveness and respiratory symptoms in a one year cohort study of Sydney school children. Eur Respir J 1993; 6: 662-669.

11. Burney PGJ, Luczynska C, Chinn S, Jarvis D, for the European Community Respiratory Health Survey. The European Community Respiratory Health Survey. Eur Respir J 1994; 7: 954-960.
12. Enarson DA, Vedal S, Schulzer M, Dybuncio A, ChanYeung M. Asthma, asthma-like symptoms, chronic bronchitis and the degree of bronchial hyperresponsiveness in epidemiologic surveys. Am Rev Respir Dis 1987; 136: 613-617.

13. Samet JM. Epidemiological approaches for the identification of asthma. Chest 1987; 91 (Suppl. 6): 74S-78S.

14. American Thoracic Society. Standardization of spirometry: 1987 update. Am Rev Respir Dis 1987; 136: 1285 1298.

15. Cox DR, Snell EJ. Analysis of binary data. 2nd edn. London, Chapman \& Hall, 1989.

16. Mosmann TR, Coffman RL. TH1 and TH2 cells: different patterns of lymphokine secretion lead to different functional patterns. Annu Rev Immunol 1989; 7: 145-173.

17. Johansson SGO. Raised levels of a new immunoglobulin class IgND in asthma. Lancet 1967; ii: 951-953.

18. Burrows B, Martinez FD, Cline MG, Lebowitz MD. The relationship between paternal and children's serum $\operatorname{IgE}$ and asthma. Am J Respir Crit Care Med 1995; 152: 1497-1500.

19. Platts-Mills TAE, Pollart SM. Asthma and serum levels of IgE (letter). N Engl J Med 1989; 320: 1696.

20. Valenta R, Duchene M, Pettenburger K, et al. Identification of profilin as a novel pollen allergen; IgE autoreactivity in sensitized individuals. Science 1991; 253: 557-559.

21. Marsh DG, Neely JD, Breazeale DR, et al. Linkage analysis of IL-4 and other chromosome 5q31.1 markers and total serum immunoglobulin E concentrations. Science 1994; 264: 1152-1156.

22. Gauchat JF, Henchoz S, Mazzei G, et al. Induction of human IgE synthesis in B-cells by mast cells and basophils. Nature 1993; 365: 340-343.

23. Bradding $\mathrm{P}$, Feather $\mathrm{IH}$, Howarth $\mathrm{PH}$, et al. Interleukin4 is localized to and released by human mast cells. $J$ Exp Med 1992; 176: 1381-1386.

24. Postma DS, Bleecker ER, Amelug PJ, e al. Genetic susceptibility to asthma: bronchial hyperresponsiveness coinherited with a major gene for atopy. $N$ Engl J Med 1995; 333: 894-900.

25. Herwerden L, Harrap SB, Wong ZY, et al. Linkage of high-affinity IgE receptor gene with bronchial hyperreactivity, even in absence of atopy. Lancet 1995; 346: 1262-1265.

26. Chinn S, Zannolin E, Lai E, Jarvis D, Luczynska CM, Burney PGJ. Adjustment of reported prevalence of respiratory symptoms for nonresponse in a multicentre health study. Int J Epidemiol 1995; 24: 603-611. 